\title{
Religious Leaders and Indonesian Religious Harmony
}

\author{
Zulkarnain Zulkarnain* and Samsuri Samsuri \\ Program Studi Pendidikan Pancasila dan Kewarganegaraan \\ Universitas Negeri Yogyakarta \\ Yogyakarta, Indonesia \\ *zulkarnain.2016@uny.ac.id
}

\begin{abstract}
Religion as one of Southeast Asian countries' identity is a matter of pride as well as a concern as a trigger of conflict if not controlled and well maintained by social actors. Religious figures are important actors in the life of the citizen's diversity. Religious figures have a major contribution to the harmony or absence of religious communities. The purpose of this study is to explore the role of religious leaders in establishing and maintaining harmony between religious communities in Indonesia with focus on research sites in Alor District. This study used ethnography study with research setting in District Teluk Mutiara. Alor Regency East Nusa Tenggaraa Province. This research shows that religious leaders have an important role in building religious tolerance in Alor society through the work of "three stoves" (religious leaders, traditional leaders, government), interfaith dialogue leaders, and then encouraging religious leaders to give religious lecture material moderate in Alor District. The three stoves continue to reproduce the harmony between religious youth in the public spaces and private religious communities in Alor. Therefore the harmony of religious people reproduced by three stoves can be one of the reference how religious figures maintain the harmony of religious communities amid religious differences.
\end{abstract}

Keywords - Indonesia; Kecamatan Alor; Religious Leaders; Religious harmony

\section{INTRODUCTION}

The presence of religion certainly cannot reach all mankind until now without the role of religious leaders. Religion and religious leaders always come together in traditional community life to a modern society. Every society that believes in religion must have a religious figure as a respected person and is believed to be the one who brings the truth from God to his followers. But in fact, in this contemporary era of religion often appear in two faces that always contradict one face with another face. From the first face, religion is a place where people discover the deepness, the depth of life, and the persistent hope. Religion is a source of inspiration and motivation for heroic acts or to arouse the spirit of sacrifice. In religion, many people draw strength faced with suffering, despair and oppression. It cannot deny that religion has a major contribution in the creation of human civilization. However, the second face sometimes denotes religion as a means of violence. In the name of religion one can impose sadistic and arbitrary others. Religion is used to discriminate both structurally and symbolically, religion is used as an excuse for acts of violence, even on murder [1]. The problem that cannot be underestimated is how to bridge the religious teachings become more and more manifest in life and not just as a means of justifying the violence and legitimacy of political power.

Countries that have religious diversity have brought many conflicts ranging from the smallest conflicts between citizens to the national level between tribes and tribes and even countries with countries. The existence of a particular religion is even used as a threat to the sustainability of other religions. So that violence both psychologically and physically cannot be avoided. The most common source of conflict with religious communities in the world is the claim that the one true religion and the other is wrong, so that the other religion is a mistake that makes other believers feel their beliefs are being harassed. Religious claims and impunity will not exist without the role of religious leaders in conveying their religious teachings to the peace and safety of their people, but on the other hand religious figures also have a major contribution in inter-religious conflicts that occur in various parts of the world. In the context of Indonesia the collapse of the new order in 1998 (reform) declaring freedom of association and opinion was included in the case of religious freedom [2].

Various studies have been carried out as a major influence of a character in the life of Bergama, for example, Myanmar is one of the countries with the worst religious conflicts in Southeast Asia in recent years. The attacks of Muslims in Myanmar came from small scale to large scale. Murders and massacres occurred on a large scale, assaults also resulted in the destruction of high places and goods belonging to Muslims in Myanmar. Military and Buddha violence in Myanmar continuously from 2012 to 2014 resulted in hundreds or even thousands of deaths in a pathetic manner, the presence of Muslims in Myanmar is considered a threat to the lives of Buddhists [3]. Thus communal violence is inevitable. This conflict certainly cannot be separated from the role of religious leaders and political elites in building public opinion about the dangers of Muslims to the lives of Buddhists in Myanmar. The anti-Muslim movement in Myanmar resulted in deep conflict and affected the political stability of the world. Different research also shows the violence that overcame the religion of the major cities in the world, one of them London. On July 7 , 2005 a suicide bomber struck London and left 52 people dead and 770 injured. Although this bombing is not done by Al-Qida but based on the investigation that religious leaders are important actors in building understanding and action to commit suicide bombings. Even quickly the government under Prime Minister Tony Blair at the time expelled a religious figure who considered justifying violence in his religious 
lectures [4]. Terror in the name of God also resulted in countries like England, France and Canada depriving the perpetrators of citizenship [5].

Indeed, religious figures are not always present in creepy form, religious leaders can also be interfaith peace actors, such as the experience of religious leaders in South Africa, where religious leaders work with other social actors against Apartheid and structural violence in South Africa [6]. In other words, religious figures have a major contribution in mobilizing society for anti-Apartheid for the sake of resistance to structural violence. This research is also supported by the results of the research [7], which shows religious figures in collaboration with The South African Faith and Family Institute (SAFFI) also contributed to the fight against gender violence against women in South Africa. The next important result of this research is [8] in his research entitled "Role of Religious Leaders in Interfaith Dialogue towards Conflict Resolution: An Islamic Perspective", explaining the magnitude of the role of religious leaders Christians in carrying out interreligious dialogue towards conflict resolution from a Christian perspective, whether it is internal dialogue with the same religion as well as external dialogue with other religions. While this article wants to provide a harmonious religious life experience among religious believers who are inherited by the ancestors and kept guarded by religious figures and other social actors in Alor District. Religious figures are one of the important actor in maintaining the harmony of religious people in Alor since the time of the ancestors until today. Religious figures continue to maintain the harmonious structure in relationships both religious and personal groups.

Alor is one of the regencies in East Nusa Tenggara Province, Republic of Indonesia. Alor consists of several islands namely Alor Island, Crocodile Island, Ternate Island, Pulau Pura and Pulau Pantar. Amidst the confusion and religious conflicts of the world, Indonesia has an area of harmonious and tolerant life in religious life $[9,10]$. The good interfaith harmony is maintained and cared for by the people of Alor, certainly supported by the actors of religious leaders. This is inversely proportional to the worse reality of world religious life. The statistical agency of Alor Regency shows that there is not one religious conflict that happened in the last 10 years. Based on these achievements Alor district received the award in the form of "Harmony Award" in 2016 and 2017. Alor's harmony just not present, but there are actors who have an important role in maintaining the harmony structure. one of which is the Religious Leader. Religious figures have a major contribution in maintaining harmony among religious believers in Alor District. Religious figures certainly do not work alone religious leaders work in keeping harmony with the term "three Furnaces". The three stoves are made up of religious leaders, traditional leaders and government. Broadly speaking, religious figures who have great contribution in maintaining harmony by reproducing pemahan about religious harmony to members of the congregation is continuously through Greja, Pure (Hindu) and mosques (Islam) in Alor Regency.

This article wants to provide an ethnographic experience of how religious leaders in the "Three Furnaces" work in maintaining the harmony of religious people and addressing the various issues among religious believers in Alor district. Alor community structure that is harmonious is a legacy of ancestors who continue to be maintained by religious leaders in cooperation with traditional leaders and government. Alor as part of the modern Indonesian state is inseparable from the ideology of Pancasila (the five basic principles of the Indonesian state), especially the first principle of "Belief in the One Supreme" [11]. The experience of religious life in Alor in this contemporary era is very important to be adopted as an alternative form of building and maintaining peace among religious believers around the world.

\section{THEORETICAL}

\section{A. Religious Figures as Harmony agents}

Religious figures are important actors in religious life. In the social theory of stout actor is discussed in theory which was sparked by Anthony Giddens namely the theory of structure [12]. In structuration theory (Structuration Theory) the relationship of actors and structures is seen as a dependency relationship with each other (mutual dependency). In theory the structure of the relationship between the actors (actions) and the structures of the duality relationships that occur in repetitive and patterned social practices across time and space. Social practice in religious life is a habit of giving direction or lecture on the importance of respecting harmony among religious followers [13]. Duality lies in the fact that something of a guidance-like structure that becomes the principle of practice in various places and times is the result of the repetition of actions acted by actors and actors in religious life.

Agents or actors are concrete people in the flow of an action and event. Structures are the rules and all resources that are formed and constitute various repetitions of social practice in a given setting of space and time. Thus, agents or actors and structures are different but can not be separated because they are the duality that exists as a result of various repetitions of social practice [14]. Furthermore Anthony Giddens explains that the structure is enabling, because it is formed by the relations of the agents in a dynamic space and time [15]. The dynamics of agents and structures show that agents have an active contribution in shaping a culture. The relationship between agents and structures that want to be seen in this research is religious actors as agents affecting social structure in the form of respecting citizens who have different religions in Indonesia so that the formation of religious harmony in Alor regency.

The Role of Three Furnaces as agents affecting the structure through the FKUB containers and religious and private events both public and private continuously from generations generates a structure of harmony among different Alor peoples of religion. This is a form of duality (between agents and structures) in the theory of Giddens' structures in the context of the reproduction of harmony perpetrated by religious figures, customs, and government of Alor Regency. This continuous reproduction not only produces a harmonious structure, but produces habits that may be according to a society or group outside Alor are not the correct means of socializing like Muslims in the Church when Christian religious events and even playing kasidah and singing spiritual songs with Muslim brothers. Vice versa, if there are religious 
events such as Muslims MTQ and so Christians take part in the committee and even do singing together and dancing lego-lego in the opening ceremony of religious events in Alor. This is the form of structure influenced by the agent (three stoves) from the time in the religious life of Alor society.

The relationship of duality between agents and structures is certainly influenced by some things according to the theory of structure. First, the significance or signification that denotes symbols, meanings, mentions and discourses in society, as in Alor society there is a symbol of ten three seven, Taramiti Tuminuku and others (see section kinship relationship), symbols of this marking serve as a discourse by the three stoves in the reproduction of peace in society Alor. Second, dominance which includes the mastery of a person or group of people both politically and custom. Three stoves in terms of dominance have everything in the domination of the people of society both in terms of economy, politics, customs, and religion. In the domination of custom it is not permissible for one to speak of custom matter if by custom rules he is not entitled because every tribe in Alor has its own rules in telling kinship ties usually the person is the descendant of head of tribe or oldest person still alive in that tribe, this will show dominance as well as show social stratification in indigenous peoples in Alor. Thirdly, Legitimacy or justification is of particular importance in adat and religion, the legitimacy of adat sanctions in Alor society has more power than other sanctions, this is due to the discourse that developed since the ancestors of Alor society and the evidence often found by Alor society. In addition, most Alor communities are more afraid of adat sanctions than religious sanctions and formal legal sanctions. Custom sanction is the sanction of the world in the form of death while religious sanction some people say can sanction the world and the hereafter. This legitimacy force makes Alor people afraid to resist adat, especially when customary leaders have spoken of adat so Alor people are very careful in acting and behaving.

The harmonious structure of the Alor community has long been the identity of the Alor community. This structure has been present even before the elements of government become an important part in the reproduction of harmony in the modern life order. Alor's ethnic, tribal and religious harmony in Alor has a long history, the tribe as one of the supports of the formation of different structures in the religious life of Alor communities with a diversity of religious and cultural communities, the structure has survived to this day, cannot be separated from the role of Three Furnaces as a leader in maintaining the continuity of harmony from generationgeneration in Alor society.

\section{METHOD}

Qualitative research in this research using ethnography method. The selection of ethnographic methods as a method of research is due to the research that will be conducted to understand and depict in depth the cultural actions in a particular society [16], in this case the cultural role of religious leaders in maintaining the harmonious structure in the SubTeluk Mutiara, Regency of Alor. This research uses six key informants. 2 from Islamic religious leaders, 2 Protestant
Christian leaders, 1 Catholic Christian and 1 Hindu religious leader.

\section{RESUlT AND DisCUSSION}

\section{A. The Presence of Religion in Alor}

The Rule of Adat is a much longer rule used by Alor ancestors before religion was present in the midst of Alor's life. The presence of Protestantism and Islam in the Alor community did not immediately dispel Alor society's beliefs until today about the various forms of adat sanctions if doing something that is not in accordance with customary procedures. Even some informants as religious leaders as well as traditional leaders reveal that religion is even set by custom.

People in general have the belief that there are forces other than the power of religion that is the strength of the ancestors, so the inheritance respects the differences not merely the call of religion but a legacy left by the ancestors. This can be seen from the phrases that show the history of kinship Alor among coastal communities (Muslim) with mountains (Protestant) society. In the expression of the custom of Alor community described as a family that is the bond of kaka-sister "kakari". Then this family split into several customary shrines namely uma Alurung lewo tallo (Alor house in three villages, all Muslims), uma ulu lewo karto (mountain man's house in ten villages, all Christians), uma Pura lewo pito (people's house temples in seven villages, mixture of Islam and Christianity) [17].

The term kakari is also used to recognize immigrants in Alor as brothers of both countrymen and fellow countrymen. Kakari on the current development is used to legitimize brotherhood not only because of the similarity of blood but also the brotherhood based on humanity and other similarities such as Language of Indonesian unity. So that religious and linguistic diversity in Alor society is not easy to be shaken, what else causes conflict of flower due to matters relating to religion.

\section{B. The Role of Religion Figure in Tiga Tungku}

Religious figures in Alor community life have an important position in the structure of society. The presence of religious leaders as a respected figure in addition to government and the custom of leaders have an impact on community loyalty to what is conveyed and desired by religious leaders who are based on religion. Religious figures not only play a role in solving problems related to theological issues. Religious figures are also present in the various problems facing the ummah.

In the pluralistic society of Alor society, the friction of conflict between communities is sometimes inevitable, religious leaders as respected people and their voices being the front guard in calming the situation in conflict situations. All informants agree if there is religious conflict, this bias is the result of the outsourced by Alor outsiders, because the brotherhood in Alor is a legacy that has been ingrained in the life of Alor community. 
All informants stated that religious leaders in conducting conflict resolution of the ummah, always prioritize dialogue with holding together adat leaders and government apparatus or kingdom before Indonesia's independence. This resolution is usually planted by "three stove" relusi. This is done by religious leaders since religions began to be present in Alor District. Three stove is a legacy of ancestors that should not be violated, if violated then the people of Alor will get calamity in the way of land, sea or air. This was acknowledged by all informants as the beliefs of the Alor community who were inherited by their ancestors. Even some places in Alor Tokoh religion can not be from ordinary people. Religious figures should be descendants of adat leaders or persons set by customary figures as religious leaders.

All religious leaders in Alor have a belief that differences are not an excuse for not living side by side because of the religious one's goal that is toward salvation in different ways. The discourse of tolerance continues to be reproduced in a structured fashion at the time of the khutbah or religious occasions. Religious figures are the most powerful actors in building awareness of tolerance by using their respective scriptural verses. In addition, religious leaders called for Alor community fraternity since the time of the ancestors who to be historical heritage to this day. It is found by researchers in various sermons in the house of worship, events of the ceremonies, government events, and custom events in various areas of Alor especially Teluk Mutiara District.

In building the discourse of brotherhood usually religious leaders in collaboration with traditional leaders in digging lineage descent seen from marriage and clan. This makes it easier for religious leaders to build interfaith discourse between different societies of religion. This is also recognized by all religious leaders as the coming of harmony Alor in the future, because the few youth who want to know the family lineage well or ask the parents.

The government has since 2016 established a forum called Forum Kerukunan Umat Beragama (FKUB) as a means by which the government is prepared to maintain inter-religious harmony in Alor. In general, it can be concluded the role of three stoves (religious figures, Government and customary leaders) in various religious-related public activities in Alor District such as Musaabaqoh Tillawatil Qur'an (MTQ) District and District level, the construction of houses of worship together has a great influence on the structure of the community of Alor in terms of religious differences. This is the identity of the true Indonesian religious figure, playing an active role in various activities in order to maintain the harmony and the Indonesian nation's dependence on the basis of different religions.

\section{CONCLUSION}

The religious figure in the ethnographic experience in Alor shows a beautiful face, where religious leaders are present as the front guard in keeping and building religious harmony, through the work of Three Furnaces, the figure with other social actors continues to reproduce the values of harmony in the sermons not only in the Pancasila mandate (five basic principles of Indonesia) and religion but, as the inheritance of the ancestors must be kept and cared for until ever. The role of religious leaders in religious harmony in Alor is one of the real forms of the noble ideals of the Indonesian nation and the world for mutual coexistence between religions. The experience of this harmony shows religious leaders have a big role in the harmony or absence of a nation-state religious life.

\section{REFERENCES}

[1] Haryatmoko. (2010). Dominasi Penuh Muslihat: Akar Kekerasan dan Diskriminasi. Jakarta: Gramedia Pustaka Utama.

[2] Rodemeier, S. (2017). Between devotion and heterodoxy. Indonesia and the Malay World, 45(131), 1-2.

[3] Cheesman, N. (2017). Introduction: Interpreting Communal Violence in Myanmar. Journal of Contemporary Asia, 47(3), 335-352.

[4] Sisk, T. D. (2011). Religious Leaders, Conflictand Peacemaking. In T. D. SiSk (Ed.), Between Terror and Tolerance: Religious Leaders, Conflict, and Peacemaking (pp. 1-9). Georgetown University Press.

[5] Joppke, C. (2016). Terror and the loss of citizenship. Citizenship Studies, 20(6-7), 728-748.

[6] Taliep, N., Lazarus, S., Seedat, M., \& Cochrane, J. R. (2016). The role of religious leaders in anti-Apartheid mobilisation: implications for violence prevention in contemporary South Africa. Religion, State and Society, 44(4), 331-348.

[7] Petersen, E. (2017). Working with religious leaders and faith communities to advance culturally informed strategies to address violence against women. Agenda Empowering Women for Gender Equity, 30(3).

[8] Karim, K. M., \& Saili, S. A. (2014). Role of Religious Leader in Interfaith Dialogue towards Conflict Resolution: An Islamic Perspective. International Journal of Education and Research, 2(6), 7788.

[9] Rodemeier, S. (2010). Islam In The Protestant Environment Of The Alor And Pantar Islands. Indonesia and the Malay World, 38(110), 27-42.

[10] Wellfet, E. (2007). Diversity \& Shared Identity: A case study of interreligious relations in Alor, Eastern Indonesia. School of Global Studies Goteborg University

[11] Hoon, C. (2017). Putting Religion into Multiculturalism: Conceptualising Religious Multiculturalism in Indonesia Putting Religion into Multiculturalism: Conceptualising Religious Multiculturalism in Indonesia. Asian Studies Review, 41(3), 476-493.

[12] Giddens A. The constitution ofsociety. 1984.

[13] B. Herry Priyono. (2002). Anthony Giddens Suatu pengantar. Jakarta: Kepustakaan Populer Gramedia.

[14] Sihotang K. Critical Thinking. Jakarta: PT Pustaka Sinar Harapan. 2012.

[15] Giddens A. The time-space constitution of social systems. InA contemporary critique of historical materialism 1995 (pp. 26-48). Macmillan Education UK.

[16] Spradley, J. P. (2007). Metode Etnografi. Yogyakarta: Tiara Wacana.

[17] Gomang, S. (2006). Muslim and Christian alliances 'Familial relationships' between inland and coastal peoples of the Belagar community in eastern Indonesia. Bijdragen Tot de Taal-, Land- En Volkenkunde, 162(4), 468-489. 